\title{
A Review of Psychological Impact on Students Online Learning during Covid-19 in Malaysia
}

\author{
Enba J. Thandevaraj, N. Azizah N. Gani, M. Khalid M. Nasir* \\ Universiti Kebangsaan Malaysia (UKM), Bangi, Malaysia \\ Email: enba_jenani@yahoo.com, nuraaziezah@gmail.com, ^mdkhalid@ukm.edu.my
}

How to cite this paper: Thandevaraj, E. J., Gani, N. A. N., \& Nasir, M. K. M. (2021). A Review of Psychological Impact on Students Online Learning during Covid-19 in Malaysia. Creative Education, 12, 1296-1306. https://doi.org/10.4236/ce.2021.126097

Received: April 26, 2021

Accepted: June 14, 2021

Published: June 17, 2021

Copyright (อ 2021 by author(s) and Scientific Research Publishing Inc. This work is licensed under the Creative Commons Attribution International License (CC BY 4.0).

http://creativecommons.org/licenses/by/4.0/ (c) (i) Open Access

\begin{abstract}
As a result of the COVID-19 pandemic crisis, e-learning has become a necessary feature in all educational establishments such as schools, colleges and universities. Teachers and students are required to adapt with the online learning method to ensure it is carried out as usual even though they have difficulties in various ways. Some of them face depressions and anxiety. This paper reviews the psychological impact on students' online learning during Covid-19 in Malaysia. Past studies determined students are affected psychologically and show symptoms of depression and anxiety. Nevertheless, many studies presented opposite results. This review suggests the government sector to take initiative in helping students with low access to the internet and gadgets which are the main requirement to be able to participate in online classes, and concurrently increase the engagement of students in virtual learning especially during this critical pandemic.
\end{abstract}

\section{Keywords}

Psychological Impact, Online Learning, Motivation, Anxiety, Covid-19

\section{Introduction}

Coronavirus also known as Covid-19 is a virus that has affected many lives. Looking at its massive spread, WHO has declared it as a pandemic. Therefore, most of the countries announced a lock down and everyone is required to work from home including those who are in the education sector. Due to the pandemic, students have gone through a roller coaster from attending physical classes every morning to studying online. Chung et al. (2020a) mentioned, the rapid transitions of Covid-19 pandemic have impacted students and lecturers in higher education institutions critically. Teachers and students around the world have faced many challenges using online platforms for teaching and learning. It 
is supported by Shahzad et al. (2020), the effects of this pandemic are unpredictable and it gives impact to the education system; most of the countries had to adapt with the new teaching and learning method.

These sorts of rapid changes could somehow affect their mental health or well-being. According to Chung et al. (2020a), although it is undeniable that online learning is considered the best solution to ensure consistency of learning in the era of the "new norm", there may be certain setbacks such as loss of human presence, detecting the incomprehension of students by facial gestures, cracking small jokes to light up the mood, student participation (Khalid \& Quick, 2016), and communication that can be achieved more effectively in class. On the bright side, this pandemic has opened opportunities for many people in various fields including teachers and students. Toquero (2020) said that global pandemic has opened up opportunities for the nation to update its current methods of education and turn its focus on utilizing technology. Thus, this paper reviewed literature on the issues of psychological impact on students' online learning during the Covid-19 pandemic.

\section{Literature Review}

\subsection{A Panacea in the Time of Covid-19}

The Covid-19 pandemic has affected the world in many aspects. According to Akat and Karatas (2020), each pandemic has had a sociological, economic and psychological impact on society and all the pandemics that occur have harmed and killed a lot of people. Throughout the period of time, all the countries affected by the pandemic were required to take action, including the education sector by enforcing the Standard Operating Procedure (SOP). As most countries started enforcing Movement Control Order (MCO), all sectors such as economy and health were required to find a solution to make their routine operate as usual and follow the procedure set by their respected government. Not to forget the education sector, where they have to stop all physical contact in school and start working from home. This is to ensure that teachers and students are not exposed to the virus.

Most education sectors chose to conduct online teaching-learning as a way to prevent the virus from spreading. Dhawan (2020) mentioned that, there was no choice but to switch completely to online teaching and learning for many academic institutions that were previously hesitant to change their traditional pedagogical approach. During this pandemic, students were unable to be at school and the lesson solely took part via online learning. Students often do not have physical interaction with the outside world and their psychological condition is somehow influenced by it. Most governments encourage those who feel mentally affected to seek help from the professionals around them or from the initiative set by the government itself. For instance, Karim (2020) stated the Ministry of Women, Family and Community Development in Malaysia formed a hotline as an initiative to provide psychological help for those who are affected by the 
stay-home order which was extended to curb the spread of the Covid-19 outbreak at the beginning. The "Talian Kasih" hotline can be called by those who are dealing with emotional breakdowns due to the MCO to seek assistance and emotional support.

\subsection{Psychological Impact on Students during Covid-19}

Folkman and Lazarus (1984) define stress as "a particular relationship between the person and the environment that is appraised by the person as taxing or exceeding his or her resources and endangering his or her well-being" (p. 19). Schools should expect students to react to the pandemic in a variety of ways that will vary depending upon the students' personal experiences and developmental level; however, it is likely that negative reactions may improve over time (Chafouleas et al., 2019). In conjunction to that, schools must be trained to discuss a wide range of psychological and physiological effects with the students, in addition to the academic requirements that would inevitably emerge as a result of the continued closing of the campus or schools.

Students are required to change their learning method from in-class to online learning. As stated by Sutarto et al. (2020) the learning process, initially was conducted face-to-face in the classroom, but has been shifted to home learning using the online system or distance learning (Nasir et al., 2018) through the use of various existing media. The online learning was used for their daily lesson and to assess their academic performance and it somehow causes the students to get stressed. It is supported by Irawan et al. (2020) where they mentioned one of the contributing factors to students' stress rate is the pressure of online lecture tasks, which requires them to use online media that they have only learned and must comprehend instantly.

This pandemic does not only mentally affect adults but also students. Corresponding to Chang et al. (2020a) and Chang et al. (2020b), they pointed out the psychological effect of the public health crisis is long lasting. The worries about pandemic usually will dissolve after a period of time. However, the impact of normalizing new things and it might affect students' academic achievement as well. Kamaludin et al. (2020) stated that fear and the risk to the health of a person can gradually dissipate as the pandemic reaches its tail end. Nevertheless, the idea of the disease itself and the desire to switch to a "new normal" will have a long-term psychological effect on the students. In exchange, this can influence the academic performance of the students.

\subsection{Motivation}

Motivation is one of the important aspects in every individual. It will help a person to perform better with determination. Motivation is needed for students and it can occur in various ways. Irvine (2018) stated that motivation is a meta definition of well-researched theoretical frameworks such as expectation-value with intrinsic-extrinsic, and involves, among others, a multitude of similar theo- 
ries such as self-efficacy, objective theory, knowledge theories, preference theory, the theory of self-determination etc. However, many students around the world had to transfer from face-to-face teaching to an online learning system in the middle of the semester due to the COVID-19 pandemic.

In general, students have limited capacity to absorb information, and it is likely that combinations of learning modalities can result in cognitive exhaustion, undermining the ability to learn new information adequately (Aguilera-Hermida, 2020). According to Unger (2007) mental wellbeing problems remain as the biggest barrier to academic achievement. It can impair students' motivation, attention and social interaction (Nasir, 2020) which are the main reason for students to excel in education. Dogan (2015) suggests that the best factors of academic achievement include; teachers must have constructive verbal motivation to promote students' academic achievement; teachers must display a positive mindset that helps inspire students, behaviors that are important to cognitive engagement (Baharudin et al., 2018) in learning environments. It would be able to inspire students to succeed academically.

\subsection{Anxiety}

Anxiety is a dynamic emotional state of tension, uneasiness, concern, and other uncomfortable feelings induced by the coming and potential danger of a person (Bauer, 1965). Reasonable anxiety is conducive to improving the brain's reaction speed and alertness, thereby improving learning effectiveness and engagement (Chen, 2019; Hordacre et al., 2016; Nasir, 2020), whereas unnecessary anxiety decreases the interest of students in learning and academic success (Khng, 2016; Ramirez et al., 2016; Scanlon et al., 2020; Cheng, 2013; Soltanlou et al., 2019). For example, in a recent study focused on Chinese medical college students, higher levels of anxiety were correlated with factors closely linked to COVID-19, such as a COVID-19-diagnosed patient (Cao et al., 2020).

Anxiety among students occurs during the lockdown because everyone was required to stay at home and all teaching and learning platforms took part virtually. Students' lost connection with human presence (Nasir, 2020) therefore it affects them mentally and emotionally. Tian et al. (2020) said that due to the possible risk of death caused by COVID-19, separation and lockdown, and the abrupt shift in teaching mode has raised the level of anxiety and generated intense pressure on most people.

Covid-19 has also got students' struggle to keep up the good result of their performance in learning that was usually done face-to-face. The determination to maintain a flying color result causes them unusual stress which also leads to serious injury. Patsali et al. (2020) said, due to the impact of Covid-19 on their performance, abnormal stress and depression among students are also associated with increased self-injury and suicide attempts. The decision taken by most governments around the world to prevent the massive spread and deaths has given a psychological effect on the public. Irfan et al. (2020) said the fear of death due to COVID-19 causes the government to take initiatives to monitor the transmis- 
sion of the virus which has impacted people and students' mental health. A largely unexplored observation is the psychological influence of COVID-19 on Malaysian students.

The 2019 Annual Report of the Center for Collegiate Mental Health found that anxiety continues to be the most prevalent issue among students who completed the Counseling Center Assessment of Psychological Symptoms, while doctors have reported that anxiety continues to be the most common condition of students seeking university counseling services. Cao et al. (2020) identify the level of anxiety among college students in China during the epidemic. The study showed how 7134 college students were affected to varying degrees during the outbreak. They found the proportion of students with mild, moderate, and extreme anxiety was $21.3 \%, 2.7 \%$ and $0.9 \%$, respectively. The factors analyze: attitude, affect, motivation, perceived behavioral control such as each use of technology, self-efficacy, and accessibility; and cognitive engagement (Nasir, 2020). The researcher has listed a variety of scholastic variables and participants were asked to gauge their understanding of how each inspired them to seek schooling before introducing the stay-at-home order. In terms of their understanding of how each inspired them to seek schooling after the stay-at-home order was enforced, participants then ranked the same variables. As well as Islam et al. (2020) and Aguilera-Hermida (2020) concluded that depressive and anxiety symptoms are crucial among students.

\subsection{Students' Perception towards Online Learning}

Online is a medium that has multiple names in academic articles, including cyber media, news websites, virtual media, e-media, network media, and modern media (Nasrullah, 2014; Nasir, 2020). As reported by Sujarwo et al. (2020) online learning is an education that takes place over the Internet. It's generally claimed to be e-learning between new phrases. However, online learning is just one form of distance learning (Nasir, 2020). With regard to the change in teaching and learning from a school-oriented method to a virtual platform through online home learning, Tahir and Noorzali (2020) stated that through the introduction of Malaysian Smart Schools, most of the teachers were introduced into the idea of online learning. Besides that, Wang et al. (2013); Wilde and Hsu (2019) claimed that digital or online teaching means that students are physically distant from teachers and need a technology that facilitates the sharing. In conjunction to that, Bower (2019); Gonzalez et al. (2020); Wang et al. (2013) stated that interaction between students and teachers is mediated by technology, and the design of learning environments may have a direct effect on learning outcomes.

Several studies have discussed the challenges related to the implementation of e-learning. The pandemic has caused a lot of changes, learning activities that were previously in a traditional classroom setting switched to an online learning environment. Changes as such could lead to minor disruption in students' wellbeing and ability to cope during the lessons. Students have found that online learning is beneficial for them, as they can get ample of access while listening to 
lectures and doing assignments. Based on prior experience with technology, students gain self-efficacy with online learning and may need preparation and assistance to use learning resources and platforms before beginning an online course (Heckel \& Ringeisen, 2019). Martin and Boliger (2018) discovered that introducing and working with online communication tools were essential communication among students while sending reminders and providing rubrics for assignments represented the most important benefit in student-teacher interactions (Nasir, 2020). Ultimately, once the student feels they have knowledge and information to help them, their use of the program would have a positive impact (Alghamdi et al., 2020; Yakubu \& Dasuki, 2019).

Zaheer et al. (2015) found that many students were happy with online education, which further revealed that e-learning in countries where higher education institutions are small would help higher education. Besides that, Popovici and Mironov (2014) notice that it becomes very clear that by their effect on the learning experience, students are profoundly aware of the changes brought about by digital technologies. The involvement of technology allows students to think out of the box. Through online learning, students are able to sharpen their ideas by thinking critically and creatively. It also will enhance their participation by involving in all the activities conducted by teachers. Chisega-Negrilă (2015) and Nasir et al. (2018) disclosed that implementing online learning resources can contribute to enhancement in critical thought, maximization of student learning, and the quality of students' participation.

Sufian et al. (2020) investigates students' perception of the Online Learning System due to the COVID-19 pandemic. Students find that learning using online tools is interactive despite always having network connection problems. Students stated that using online tools are not difficult and at the same time trains them to get the work done. It shows a positive outcome on the use of online learning tools among students. While Agung et al. (2020) mentioned that carrying out online learning has many impacts. Some students found that during online learning, their IT literacy made strong progress. Students get to enjoy the experience of using online learning and it improves their skills on finding information. It also helps them to become independent and responsible in completing their task. Students have also mentioned it is a challenge because it required more reading on their own. On the other hand, it also showed that even though most of them had a poor internet connection and ample internet data/quota at their home, the students were committed to joining the online course. This is because they can get access to the resources used in the class anytime.

Ana et al. (2020) study on students' perception on preparing themselves before joining the learning activities found that $24 \%$ of students stated it is easy to prepare for e-learning activities, $26 \%$ of students stated the learning material was sufficient, $21 \%$ stated the teaching material for online class were provided and $20 \%$ of the students mentioned the lesson plan aspect was adequate. The results are important as it allows the lesson to be conducted as planned. Students will definitely have problems attending classes if any one of the criteria is lacking. All 
these criteria help students to get encouraged and allow them to participate in the online learning class.

\section{Conclusion}

There are many studies that have proven psychological impact on students due to COVID-19 and the changes of traditional classrooms to an online environment. This is in line with Sujarwo et al. (2019) who believe that learning practices can be conveniently carried out by learners anywhere as they are not constrained by time and space. Online learning seems to be the best choice for teaching and learning in a pandemic Covid-19, particularly for students who have good internet facilities. However, online learning has a negative effect ( $\mathrm{Ab}$ oagye et al., 2020; Putra et al., 2020; Sufian et al., 2020). For instance, students have trouble accessing online learning due to an insufficient network and have to use their mobile phones on an ongoing basis. This causes them to be left out from the lessons that were conducted and it affects their academic achievement. These factors lead students to have depression and anxiety (Kalok et al., 2020; Odriozola-González et al., 2020). It is suggested that the government sector must take steps to assist students with poor internet connectivity and gadgets that are the key prerequisite to be eligible to enroll in online courses. It will also serve to decrease the percentage of mentally impaired students due to their academic achievement. In short, this review paper highlights issues encountered by students and educators during the coronavirus pandemics. They were not prepared for a full online experience, internet issues, lack of gadgets and social support due to the depression and anxiety.

\section{Acknowledgements}

This research was funded by the Faculty of Education's research grant, Universiti Kebangsaan Malaysia (UKM) under the project code GG-019-021. The researchers would like to thank Ts. Dr. M. Khalid M. Nasir as well as the Faculty of Education, UKM, for the opportunity to write this paper. The researchers would also like to express their gratitude to their family members.

\section{Conflicts of Interest}

The authors declare no conflicts of interest regarding the publication of this paper.

\section{References}

Aboagye, E., Yawson, J. A., \& Appiah, K. N. (2020). COVID-19 and e-Learning: The Challenges of Students in Tertiary Institutions. Social Education Research, 2, 1-8. https://doi.org/10.37256/ser.122020422

Aguilera-Hermida, A. P. (2020). College Students' Use and Acceptance of Emergence Online Learning Due to Covid-19. International Journal of Educational Research Open, 1, 100011. https://doi.org/10.1016/j.ijedro.2020.100011

Agung, A. S. N., Surtikanti, M. W., \& Quinones, C. A. (2020). Students' Perception of 
Online Learning during COVID-19 Pandemic: A Case Study on the English Students of STKIP Pamane Talino. Soshum: Jurnal Sosial dan Humaniora, 10, 225-235. https://doi.org/10.31940/soshum.v10i2.1316

Akat, M., \& Karataş, K. (2020). Psychological Effects of COVID-19 Pandemic on Society and Its Reflections on Education. Electronic Turkish Studies, 15(4).

Alghamdi, A., Karpinski, A. C., Lepp, A., \& Barkley, J. (2020). Online and Face-to-Face Classroom Multitasking and Academic Performance: Moderated Mediation with Self-Efficacy for Self-Regulated Learning and Gender. Computers in Human Behavior, 102, 214-222. https://doi.org/10.1016/j.chb.2019.08.018

Ana, A., Minghat, A. D., Purnawarman, P., Saripudin, S., Muktiarni, M., Dwiyanti, V., \& Mustakim, S. S. (2020). Students' Perceptions of the Twists and Turns of E-learning in the Midst of the Covid 19 Outbreak. Romanian Journal for Multidimensional Education/Revista Romaneasca pentru Educatie Multidimensionala, 12, 15-26. https://doi.org/10.18662/rrem/12.1sup2/242

Baharudin, H., Nasir, M. K. M., Yusoff, N. M. R. N., \& Surat, S. (2018). Assessing Students' Course Satisfaction with Online Arabic Language Hybrid Course. Advanced Science Letters, 24, 350-352. https://doi.org/10.1166/asl.2018.12005

Bauer, J. (1965). Definition(s) of Anxiety. The Journal of the American Medical Association, 191, 420. https://doi.org/10.1001/jama.1965.03080050066027

Bower, M. (2019). Technology-Mediated Learning Theory. British Journal Education Technology, 50, 1035-1048. https://doi.org/10.1111/bjet.12771

Cao, W., Fang, Z., Hou, G., Han, M., Xu, X., Dong, J., \& Zheng, J. (2020). The Psychological Impact of the COVID-19 Epidemic on College Students in China. Psychiatry Research, 287, Article ID: 112934. https://doi.org/10.1016/j.psychres.2020.112934

Center for Collegiate Mental Health (2020). The 2019 Annual Report. University Park, PA: Penn State University.

https://ccmh.memberclicks.net/index.php?option=com content\&view=article\&id=62:a nnual-reports\&catid=20: site-content\&Itemid $=167$

Chafouleas, S. M., Koriakin, T. A., Roundfield, K. D., \& Overstreet, S. (2019). Addressing Childhood Trauma in School Settings: A Framework for Evidence-Based Practice. School Mental Health, 11, 40-53. https://doi.org/10.1007/s12310-018-9256-5

Chang, J. H., Yuan, Y. X., \& Wang, D. (2020). Mental Health Status and Its Influencing Factors among College Students during the Epidemic of COVID-19. Journal of Southern Medical University, 40, 171-176.

Chen, Y. (2019). Effect of Mobile Augmented Reality on Learning Performance Motivation and Math Anxiety in a Math Course. Journal of Educational Computing Research, 57, 1695-1722. https://doi.org/10.1177/0735633119854036

Cheng, S.-Y. S. (2013). An Empirical Investigation of the Effectiveness of Project-Based Course Learning within Hospitality Programs: The Mediating Role of Cognitive Engagement. Journal of Hospitality Leisure Sport \& Tourism Education, 13, 213-225. https://doi.org/10.1016/j.jhlste.2013.10.002

Chisega-Negrilă, A. M. (2015). Using Social Media for ESL Learning-Twitter vs. Pinterest. Journal of Advanced Distributed Learning Technology, 3, 75-96.

Chung, E., Noor, N. M., \& Mathew, V. N. (2020a). Are You Ready? An Assessment of Online Learning Readiness among University Students. International Journal of Academic Research in Progressive Education and Development, 9, 301-317.

Chung, E., Subramaniam, G., \& Dass, L. C. (2020b). Online Learning Readiness among University Students in Malaysia amidst COVID-19. Asian Journal of University Educa- 
tion, 16, 46-58. https://doi.org/10.24191/ajue.v16i2.10294

Dhawan, S. (2020). Online Learning: A Panacea in the Time of COVID-19 Crisis. Journal of Educational Technology Systems, 49, 5-22. https://doi.org/10.1177/0047239520934018

Dogan, U. (2015). Student Engagement, Academic Self-Efficacy, and Academic Motivation as Predictors of Academic Performance. The Anthropologist, 20, 553-561. https://doi.org/10.1080/09720073.2015.11891759

Folkman, S., \& Lazarus, R. S. (1984). Stress, Appraisal, and Coping (pp. 150-153). New York: Springer Publishing Company.

Gonzalez, T., de la Rubia, M. A., Hincz, K., Comas-Lopez, M., Subirats, L., Fort, S. et al. (2020). Influence of COVID-19 Confinement in Students' Performance in Higher Education. PLoS ONE, 15, e0239490. https://doi.org/10.35542/osf.io/9zuac

Heckel, C., \& Ringeisen, T. (2019). Pride and Anxiety in Online Learning Environments: Achievement Emotions as Mediators between Learners' Characteristics and Learning Outcomes. Journal of Computer Assisted Learning, 35, 667-677.

https://doi.org/10.1111/jcal.12367

Hordacre, B., Immink, M. A., Ridding, M. C., \& Hillier, S. (2016). Perceptual-Motor Learning Benefits from Increased Stress and Anxiety. Human Movement Science, 49, 36-46. https://doi.org/10.1016/j.humov.2016.06.002

Irawan, A. W., Dwisona, D., \& Lestari, M. (2020). Psychological Impacts of Students on Online Learning during the Pandemic COVID-19. KONSELI: Jurnal Bimbingan dan Konseling (E-Journal), 7, 53-60. https://doi.org/10.24042/kons.v7i1.6389

Irfan, M., Shahudin, F., Hooper, V., Akram, W., \& Ghani, R. (2020). The Psychological impact of Coronavirus on University Students and Its Socio-Economic Determinants in Malaysia. medRxiv. https://doi.org/10.1101/2020.10.27.20220723

Irvine, J. (2018). A Framework for Comparing Theories Related to Motivation in Education. Research in Higher Education Journal, 35, 1-30.

Islam, M. A., Barna, S. D., Raihan, H., Khan, M. N. A., \& Hossain, M. T. (2020). Depression and Anxiety among University Students during the COVID-19 Pandemic in Bangladesh: A Web-Based Cross-Sectional Survey. PLoS ONE, 15, e0238162. https://doi.org/10.1371/journal.pone.0238162

Kalok, A., Sharip, S., Abdul Hafizz, A. M., Zainuddin, Z. M., \& Shafiee, M. N. (2020). The Psychological Impact of Movement Restriction during the COVID-19 Outbreak on Clinical Undergraduates: A Cross-Sectional Study. International Journal of Environmental Research and Public Health, 17, 8522. https://doi.org/10.3390/ijerph17228522

Kamaludin, K., Chinna, K., Sundarasen, S., Khoshaim, H. B., Nurunnabi, M., Baloch, G. M., Sukayt, A., \& Hossain, S. F. A. (2020). Coping with COVID-19 and Movement Control Order (MCO): Experiences of University Students in Malaysia. Heliyon, 6, e05339. https://doi.org/10.1016/j.heliyon.2020.e05339

Karim, K. N. (2020). 24-Hour Talian Kasih Hotline to Help Deal with Mental Turmoil during $M C O$.

https://www.nst.com.my/news/nation/2020/03/578373/24-hour-talian-kasih-hotline-he lp-deal-mental-turmoil-during-mco

Khalid, N. M., \& Quick, D. (2016). Teaching Presence Influencing Online Students' Course Satisfaction at an Institution of Higher Education. International Education Studies, 9, 62-70. https://doi.org/10.5539/ies.v9n3p62

Khng, K. H. (2016). A Better State-of-Mind: Deep Breathing Reduces State Anxiety and Enhances Test Performance through Regulating Test Cognitions in Children. Cogni- 
tion and Emotion, 31, 1502-1510. https://doi.org/10.1080/02699931.2016.1233095

Martin, F., \& Bolliger, D. U. (2018). Engagement Matters: Student Perceptions on the Importance of Engagement Strategies in the Online Learning Environment. Online Learning, 22, 205-222. https://doi.org/10.24059/olj.v22i1.1092

Nasir, M. K. M. (2020). The Influence of Social Presence on Students' Satisfaction toward Online Course. Open Praxis, 12, 485-493. https://doi.org/10.5944/openpraxis.12.4.1141

Nasir., M. K. M., Mansor, A. Z., \& Rahman, M. J. A. (2018). Measuring Malaysian Online University Student Social Presence in Online Course Offered. Journal of Advanced Research in Dynamical and Control Systems, 10, 1442-1446.

Nasrullah, R. (2014). Teori dan Riset Media Siber (Cybermedia). Jakarta: Prenamed Group.

Odriozola-González, P., Planchuelo-Gómez, Á., Irurtia, M. J., \& de Luis-García, R. (2020). Psychological Effects of the COVID-19 Outbreak and Lockdown among Students and Workers of a Spanish University. Psychiatry Research, 290, 113108. https://doi.org/10.1016/j.psychres.2020.113108

Patsali, M. E., Mousa, D. P. V., Papadopoulou, E. V., Papadopoulou, K. K., Kaparounaki, C. K., Diakogiannis, I., \& Fountoulakis, K. N. (2020). University Students' Changes in Mental Health Status and Determinants of Behavior during the COVID-19 Lockdowns in Greece. Psychiatry Research, 292, 113298. https://doi.org/10.1016/j.psychres.2020.113298

Popovici, A., \& Mironov, C. (2014). Students' Perception on Using eLearning Technologies. Procedia-Social and Behavioral Sciences, 180, 1514-1519.

https://doi.org/10.1016/j.sbspro.2015.02.300

Putra, P., Liriwati, F. Y., Tahrim, T., Syafrudin, S., \& Aslan, A. (2020). The Students Learning from Home Experiences during Covid-19 School Closures Policy in Indonesia. Jurnal Iqra': Kajian Ilmu Pendidikan, 5, 30-42. https://doi.org/10.25217/ji.v5i2.1019

Ramirez, G., Chang, H., Maloney, E. A., Levine, S. C., \& Beilock, S. L. (2016). On the Relationship between Math Anxiety and Math Achievement in Early Elementary school: The Role of Problem-Solving Strategies. Journal of Experimental Child Psychology, 141, 83-100. https://doi.org/10.1016/j.jecp.2015.07.014

Scanlon, C. L., Toro, J. D., \& Wang, M.-T. (2020). Socially Anxious Science Achievers: The Roles of Peer Social Support and Social Engagement in the Relation between Adolescents' Social Anxiety and Science Achievement. Journal of Youth and Adolescence, 49, 1005-1016. https://doi.org/10.1007/s10964-020-01224-y

Shahzad, A., Hassan, R., Aremu, A. Y., Hussain, A., \& Lodhi, R. N. (2020). Effects of COVID-19 in E-Learning on Higher Education Institution Students: The Group Comparison between Male and Female. Quality \& Quantity, 55, 805-826.

https://doi.org/10.1007/s11135-020-01028-Z

Soltanlou, M., Artemenko, C., Dresler, T., Fallgatter, A. J., Ehlis, A. C., \& Nuerk, H. C. (2019). Math Anxiety in Combination with Low Visuospatial Memory Impairs Math Learning in Children. Frontiers in Psychology, 10, 89.

https://doi.org/10.3389/fpsyg.2019.00089

Sufian, S. A., Nordin, N. A., Tauji, S. S. N., \& Nasir, M. K. M. (2020). The Impact of Covid-19 on the Malaysian Education System. International Journal of Academic Research in Progressive Education \& Development, 9, 764-774. https://doi.org/10.6007/IJARPED/v9-i2/7659

Sujarwo, S., Sukmawati, S., Akhiruddin, A., Ridwan, R., \& Siradjuddin, S. S. S. (2020). An Analysis of University Students' Perspective on Online Learning in the Midst of Covid-19 Pandemic. Jurnal Pendidikan Dan Pengajaran, 53, 125-137. https://doi.org/10.23887/jpp.v53i2.24964 
Sujarwo, Sukmawati, \& Yahrif, M. (2019). Model-Model Pembelajaran: Pendekatan Saintifik dan Inovatif(Jalal, Ed.). Serang Banten: CV.AA.Rizky. http://www.aarizky.com/

Sutarto, S., Sari, D. P., \& Fathurrochman, I. (2020). Teacher Strategies in Online Learning to Increase Students' Interest in Learning during COVID-19 Pandemic. Jurnal Konseling dan Pendidikan, 8, 129-137. https://doi.org/10.29210/147800

Tahir, A. N., \& Noorzali, I. (2020). Sedia hadapi kelas maya sesuai normal baharu. Berita Harian Online.

https://www.bharian.com.my/berita/nasional/2020/04/679003/sedia-hadapi-kelas-may a-sesuai-normal-baharu

Tian, F., Li, H., Tian, S., Yang, J., Shao, J., \& Tian, C. (2020). Psychological Symptoms of Ordinary Chinese Citizens Based on SCL-90 during the Level I Emergency Response to COVID-19. Psychiatry Research, 288, 112992.

https://doi.org/10.1016/j.psychres.2020.112992

Toquero, C. M. (2020). Challenges and Opportunities for Higher Education amid the COVID-19 Pandemic: The Philippine Context. Pedagogical Research, 5, Article No. em0063. https://doi.org/10.29333/pr/7947

Unger, K. (2007). Handbook on Supported Education: Providing Services for Students with Psychiatric Disabilities. Charleston, SC: BookSurge Publishing.

Wang, C.-H., Shannon, D. M., \& Ross, M. E. (2013). Students' Characteristics, Self-Regulated Learning, Technology Self-Efficacy, and Course Outcomes in Online Learning. Distance Education, 34, 302-323. https://doi.org/10.1080/01587919.2013.835779

Wilde, N., \& Hsu, A. (2019). The Influence of General Self-Efficacy on the Interpretation of Vicarious Experience Information within Online Learning. International Journal of Educational Technology in Higher Education, 16, Article No. 26. https://doi.org/10.1186/s41239-019-0158-x

Yakubu, M. N., \& Dasuki, S. I. (2019). Factors Affecting the Adoption of e-Learning Technologies among Higher Education Students in Nigeria: A Structural Equation Modeling Approach. Information Development, 35, 492-502. https://doi.org/10.1177/0266666918765907

Zaheer, M., Babar, M. E., Gondal, U. H., \& Qadri, M. M. (2015). E-Learning and Student Satisfaction. In Proceedings of the 29th Annual Conference of the Asian Association of Open Universities: New frontiers in $O D L$ (pp. 275-285). Kuala Lumpur, Malaysia. 